\title{
Intolerance and Political Repression in the United States: A Half Century after McCarthyism
}

\author{
James L. Gibson Washington University in St. Louis
}

\begin{abstract}
What consequences for political freedom arise from high levels of political intolerance among the American public? Comparing surveys from 1954 to 2005, I document the level of perceived freedom today and consider how it has changed since the McCarthy era. Levels of intolerance today and in 1954 are also compared. Next assessed is whether restrictions on freedom are uniformly perceived or whether some subsections of the population are more likely to feel repressed than others. I find that while intolerance may have declined somewhat since 1954, perceived constraints on individual freedom have actually increased. These findings produce telling consequences for the subtheory of pluralistic intolerance. During McCarthyism, intolerance focused on the Left; today, many groups are not tolerated, so the loss of freedom is more widespread. Heretofore, many thought that pluralistic intolerance tended to be benign. At least in the case of the contemporary United States, it seems not to be.
\end{abstract}

$\mathrm{O}$ ver the course of American history, the willingness of the state to "put up with" political dissidents has waxed and waned. During some eras, quite robust political debate has been tolerated, but during other periods, political orthodoxy has prevailed. The range of beliefs safe to express in the United States has varied considerably over time (see, for example, Stone 2004).

Fifty years ago, the Americans witnessed a major outbreak of political intolerance and repression. During this infamous period named after its leader, the Republican Senator from Wisconsin, only the most centrist political differences were tolerated. To many, McCarthyism stands as one of the most shameful episodes of intolerance in modern American history. ${ }^{1}$
The McCarthy period is notable as well because it stimulated social scientists to launch important studies of the intolerance of ordinary people. No such study is more renowned than that conducted by Samuel Stouffer (1955). Stouffer's research, based on interviews with representative national samples, focused on the degree to which ordinary people would put up with threatening political ideas. His results shocked many: Of 4,933 respondents interviewed, only 113 people-a paltry $2.3 \%$-would not restrict the activities and rights of an admitted Communist in some way. ${ }^{2}$ Local community leaders, on the other hand, expressed considerably less appetite for intolerance. Out of Stouffer's research emerged highly influential "elitist" theories of democracy (e.g., Bachrach 1967), as well as an intellectual concern that has persisted for 50 years

James L. Gibson is Sidney W. Souers professor of government and director, Program on Citizenship and Democratic Values, Weidenbaum Center on the Economy, Government, and Public Policy, Washington University in St. Louis, Campus Box 1063, 219 Eliot Hall, St. Louis, MO 63130-4899 (jgibson@wustl.edu). Professor Gibson is also a fellow at the Centre for Comparative and International Politics, Stellenbosch University (South Africa).

This is a revised version of a paper prepared for delivery at the 2005 "Workshop for Preliminary Presentations of Findings from the Citizenship, Involvement, Democracy (CID) Survey Project," Center for Democracy and the Third Sector (CDATS), Georgetown University. Support for the research on which this article is based has been provided by the Atlantic Philanthropies in a grant to the Center for Democracy and the Third Sector (CDATS) at Georgetown University, and by the Weidenbaum Center on the Economy, Government, and Public Policy at Washington University in St. Louis. Marc Morjé Howard, with the assistance of James L. Gibson, was primarily responsible for executing that survey. I greatly appreciate Howard's untiring efforts on the 2005 project, as well as the support for this research provided by Steven S. Smith of the Weidenbaum Center at Washington University in St. Louis. I also appreciate the research assistance of Marc Hendershot, Jessica Flanigan, and Eric Wolfish and the comments of E. J. Dionne on an earlier draft of this article.

${ }^{1}$ On McCarthyism and intolerance see Goldstein (1978), Gibson (1988), and Peffley and Sigelman (1989).

${ }^{2}$ Stouffer asked his respondents nine questions about placing restrictions on the activities of an admitted Communist. The responses ranged from the $89.6 \%$ who would fire the Communist from a job working in a defense plant (and the $89.4 \%$ who would fire the Communist from a job teaching in a university) to a "low" of $35.5 \%$ who would stop buying a brand of soap that was plugged by a Communist on a radio show.

American Journal of Political Science, Vol. 52, No. 1, January 2008, Pp. 96-108 
about the causes and consequences of the intolerance of ordinary citizens. ${ }^{3}$

The United States in the post-9/11 era is said by some observers to have entered a new period of McCarthyism. Critics point, for example, to such legislation as the Patriot Act as evidence that the spirit of the Republican Senator still casts a long shadow over the land (e.g., Baker and Kavanagh 2005). On its face, this claim seems unlikely to be true: Loyalty oaths are not today commonplace, no investigations have been launched into subversive influences within powerful institutions such as Hollywood or the U.S. Army, and the number of people losing their jobs owing to their political views is not large (although nor is it zero). ${ }^{4}$ A reasonable view of public policy in the current period is that freedom has been restricted-especially for those without the protection of American citizenshipbut that widespread political repression has not yet materialized. Nonetheless, an appreciable threat exists that more draconian restraints on political freedom will be put in place in the future, especially if there is another direct attack on American soil.

Social scientists have been slow to contribute to the debate over intolerance and repression in the contemporary United States (but see Davis 2007; see also Davis and Silver 2004 and Rasinski et al. 2002). How does the current period compare to the McCarthy past? How intolerant are Americans today? Is more or less freedom available to citizens than during the McCarthy era? To what degree is intolerance concentrated on particular groups or ideologies; is the contemporary period an example of what happens when intolerance becomes focused rather than pluralistic (e.g., Sullivan, Piereson, and Marcus 1982)? In short, how much freedom has been lost to $9 / 11$, and whose freedom is being sacrificed today? The purpose of this article is to provide answers to these questions based primarily on a nationally representative survey conducted in 2005 and the original Stouffer survey data. In addition, since many of the same questions were put to a nationally representative sample in 1987 (e.g., Gibson 1992a), comparison is also made to that period of American politics.

\footnotetext{
${ }^{3}$ For useful reviews of the tolerance literature see Sullivan and Transue (1999) and Gibson (2007).

${ }^{4}$ For example, Brown (1958) estimated that out of the workforce of 65 million, 13 million were affected by loyalty and security programs during the McCarthy era. Furthermore, more than 11,000 individuals were fired as a result of government and private loyalty programs. More than 100 people were convicted under the federal Smith Act, and 135 people were cited for contempt by the House Un-American Activities Committee. Nearly one-half of the social science professors teaching in universities at the time expressed medium or high apprehension about possible adverse repercussions to them as a result of their political beliefs and activities (Lazarsfeld and Thielens 1958). The Communist Party was essentially obliterated. By comparison, the post-9/11 repression seems quite limited.
}

The theory tested in considering these questions is that of pluralistic intolerance. This theory, developed by Sullivan, Piereson, and Marcus (1982; see also Gibson 1986, 1998), asserts that the likelihood that intolerance will be benign rises if it is unfocused (pluralistic). In the 1950s, intolerance was sharply focused on left-wing dissenters. Today, some suspect that intolerance is concentrated on Muslim extremists. To the extent that the enemies of the system are clearly defined-whomever that may be at any given moment in history-intolerance becomes concentrated and is likely to have pernicious consequences, such as the limitation of individual political freedom. Thus, this research, unlike most studies in the subfield, focuses upon the consequences of political intolerance for political freedom in a democratic political system.

The empirical portion of this analysis begins with an examination of the degree of political freedom existing today in comparison to Stouffer's 1954 survey. Do Americans today perceive less freedom as being available to them, compared to the McCarthy era? The freedom assessed here is individual perceptions of liberty-the degree to which people feel that they can express their political views with relative impunity.

How does political intolerance compare between now and 50 years ago? Although Communists no longer represent the threat that the Americans perceived in the early 1950s, the data provide some ability to compare contemporary levels of political intolerance with that of the 1950s. ${ }^{5}$ Throughout most of this analysis, interracial differences are hypothesized (and in fact discovered).

\footnotetext{
${ }^{5}$ Given the small number of data points, it is of course impossible to conduct any rigorous analysis of the relationship between objective sociopolitical environmental variables and levels of mass political intolerance. Nonetheless, it is interesting to consider the relationship between aggregate levels of threat and intolerance. Using McCann's measures of threat-defined as referring to "what might be considered as threats or stressors of crises of a social, economic, or political nature faced by the populace or by substantial portions of the populace" (McCann 1998, 435) -I note that in 1954 the threat score was 3.4 and in 1987 it was 3.8 (on a seven-point scale, with high scores indicating more threat). However, threat declined significantly between 1953 and 1954 (from 4.2 to 3.4), and threat was even higher in the period from 1950 to 1952. McCann's scores end in 1992, so none are available for the period around the 2005 survey. Moreover, we have no idea how these objective measures map onto subjective perceptions. Nonetheless, it is not implausible that levels of objective threat were roughly comparable in 1954, 1987, and 2005, and that 1954 and 2005 may be especially similar in that both years reflect some lessening of tensions after a period of relatively intense conflict (the Korean War and the 9/11 attack). The many hazards of making this sort of gross comparison of time periods, however, warn against pursuing this sort of analysis much further, even if we can have considerable confidence that threat was focused in the early 1950 s.
} 
In the final portion of the analysis, the distribution of these attitudes within the American public is analyzed. In particular, I assess whether those who are sympathetic to various groups are more likely to be intolerant and to perceive constraints on their freedom. Perhaps the most interesting finding here is that sympathizers with relatively extreme groups are not necessarily those who perceive the greatest limitations on their political freedom in the contemporary United States. This may be a function of the dispersed-or perhaps a better word is "multifocused" nature of intolerance today. The most important theoretical conclusion of this analysis is that the subtheory of pluralistic intolerance ${ }^{6}$ must be reconceptualized to acknowledge that even unfocused intolerance can create a culture of conformity that discourages those with unpopular views from asserting themselves politically.

\section{Pluralistic Intolerance}

One of the most important ideas to emerge from the tolerance literature is the subtheory of pluralistic intolerance. According to Sullivan, Piereson, and Marcus (1982), lack of consensus on who the enemy ispluralistic intolerance-can neutralize even widespread intolerance (even if it does not necessarily do so, as for example, in the case of determined, intolerant elites). When everyone selects a different group as his or her most hated foe, the result may be that insufficient agreement exists for intolerance to be mobilized into political repression. When intolerance is pluralistic, it is dispersed and may therefore be relatively benign.

The underlying assumption of the subtheory of pluralistic intolerance is that a united public will most likely succeed in getting what it wants; to the extent that people agree in identifying the predominant threat to a political system, their demands for political repression will ring loudly in the ears of their representatives. This simple "demand input" model—what people want they getdrives the subtheory of pluralistic intolerance. The theory

\footnotetext{
${ }^{6}$ I refer to this as a "subtheory" because the set of propositions provides an understanding of the ways in which public opinion gets connected to political repression, rather than a full-blown theory of all possible causes of the outbreak of repression (for instance, the focusing of opinion may raise the likelihood of repression even if it does not guarantee it). "Subtheory" is also an appropriate term because it is embedded within a larger theory of democratic breakdown and repression breakout: In a democracy, when a majority of the people are in agreement about something they want, they are more likely to get it because institutions of majority rule facilitate (but not guarantee) the translation of public preferences into public policy. Thus, although slightly awkward, I will refer to the "subtheory of pluralistic intolerance" throughout this article.
}

strongly emphasizes the need to identify the factors contributing to the focusing and unfocusing of intolerance, for it is focused intolerance that can be dangerous and pernicious (see Sullivan et al. 1985).

Unfortunately, little rigorous research at the system level (either over time or cross-nationally) has investigated the subtheory of pluralistic intolerance. In their microlevel research on South Africa, Gibson and Gouws (2003) discovered that intolerance can be both focused and pluralistic, in the sense that many groups, of various ideological affinities, may not be tolerated by people. Gibson (1998), on the other hand, asserts that intolerance is focused on the far right wing in Russia. More research needs to be conducted to determine the "breadth" of tolerance in different societies - the range of ideas that people believe can be legitimately expressed in a society.

One important limitation of the subtheory of pluralistic intolerance is that its primary (if not exclusive) focus is on repression brought about via public policy (the "demand input" model). Some research has found the linkage between ordinary citizens and policy makers to be weak or nonexistent (e.g., Gibson 1988), so even focused public intolerance may not always produce political repression. And perhaps even when the majority of people are not united in their intolerance, important political consequences may flow.

An alternative pathway of influence is via cultural norms of conformity. Intolerance may constrain freedom not through government-sponsored public policies but rather through norms discouraging disagreement and sanctioning opinions deviating very far from the mainstream. Tocqueville observed long ago that "I know of no country in which there is so little independence of mind and real freedom of discussion as in America" (1948, vol. 1, 263). In Noelle-Neumann's "spiral of silence" people are encouraged "either to proclaim their views or to swallow them and keep quiet until, in a spiraling process, the one view dominated the public scene and the other disappeared from public awareness as its adherents became mute" $(1984,5)$. To the extent that unpopular views are sanctioned through interpersonal mechanisms, it may be unnecessary for a majority of the people to be intolerant of an idea. Moreover, the homogeneity of social networks may make it easy to identify those with aberrant views, entirely apart from the overall distribution of opinions within a country. As Mutz has noted: "If people are surrounded by people who think much like they do, they will be less aware of the legitimate arguments on the other side of contemporary political controversies... The capacity to see that there is more than one side to an issue, that a political conflict is, in fact, a legitimate controversy with rationales on both sides, translates to greater willingness 
TABle 1 Perceptions of Political Freedom, 1954-2005

\begin{tabular}{|c|c|c|c|}
\hline & \multicolumn{3}{|c|}{ Year of Survey } \\
\hline & 1954 & 1987 & 2005 \\
\hline \multicolumn{4}{|l|}{ Which of these three views is closest to your own? } \\
\hline All people feel as free to say what they think as they used to. & 55.6 & 52.6 & 42.6 \\
\hline Some people do not feel as free to say what they think as they used to. & 30.7 & 39.4 & 45.7 \\
\hline Hardly anybody feels as free to say what he thinks as he used to. & 9.9 & 7.4 & 9.9 \\
\hline Don’t Know & 3.8 & .5 & 1.8 \\
\hline Total & $100 \%$ & $100 \%$ & $100 \%$ \\
\hline $\mathrm{N}$ & 4933 & 1218 & 995 \\
\hline \multicolumn{4}{|l|}{$\begin{array}{l}\text { What about you personally? Do you or don't you feel as free to speak } \\
\text { your mind as you used to? }\end{array}$} \\
\hline Yes, as free & 84.7 & 78.9 & 75.6 \\
\hline No, less free & 13.4 & 20.5 & 24.1 \\
\hline Don't Know & 1.9 & .5 & .3 \\
\hline Total & $100 \%$ & $100 \%$ & $100 \%$ \\
\hline $\mathrm{N}$ & 4929 & 1219 & 993 \\
\hline
\end{tabular}

to extend civil liberties to even those groups whose political views one dislikes a great deal" (2002, 122; emphasis in the original). The existence of a homogeneous social network can therefore exacerbate the consequences of intolerance, quite apart from any linkage to repressive public policy (see also Huckfeldt, Ikeda, and Pappi 2005).

In general, the subtheory of pluralistic intolerance is largely silent about the cultural consequences of mass political intolerance. It is therefore important that research address the question of how free ordinary people feel to express their political views. Fortunately, Stouffer's survey specifically addressed this matter, so a useful comparative baseline from the McCarthy era is available.

\section{Political Freedom, Then and Now}

How does the contemporary period in the United States compare with the McCarthy era with regard to the political freedom available to ordinary citizens? There are many ways in which levels of political freedom might be measured, as, for instance, in studies of the degree of freedom proclaimed by statutes and constitutions. Following Stouffer and others (e.g., Gibson 1992a), my approach here is to conceptualize freedom as an individual-level perception. From this viewpoint, the appropriate way to measure freedom is to ask individuals about the constraints they perceive on their ability to express their polit- ical views without repercussions from those around them or from the state. ${ }^{7}$

Stouffer began his inquiry into perceived liberty in 1954 by asking the respondents to estimate the degree to which others enjoyed political freedom. ${ }^{8}$ The Stouffer items were repeated on a national, face-to-face survey conducted in 1987 (see, for example, Gibson 1992a $\mathrm{a}^{9}$ ). A comparison of those two earlier surveys with the contemporary data is reported in Table $1 .^{10}$

The data in this table provide some evidence that freedom, or least the perception of freedom, has actually

${ }^{7}$ For earlier research based on this approach, see Gibson (1992a, 1993). In those articles, the distinction between objectively available freedom and subjectively perceived freedom is addressed and refined.

${ }^{8}$ Stouffer's data are available from ICPSR (Study \# 7202). The interviews in 1954 were of course conducted face-to-face.

${ }^{9}$ The Freedom and Tolerance Survey (Study \# 9454) is available from ICPSR.

${ }^{10}$ This research is based on a nationally representative sample interviewed face-to-face during the summer of 2005. The field work took place from mid-May until mid-July 2005. A total of 1,001 interviews was completed, with a response rate of $40.03 \%$ (AAPOR Response Rate \#3). No respondent substitution was allowed; up to six callbacks were executed. The average length of interview was 83.8 minutes (with a standard deviation of 23.9 minutes). The data were subjected to some minor "post-stratification," with the proviso that the weighted numbers of cases must correspond to the actual number of completed interviews. Interviews were offered in both English and Spanish (with the Spanish version of the questionnaire prepared through conventional translation/backtranslation procedures). Samples such as this have a margin of error of approximately $\pm 3.08 \%$. 
declined in the United States since the McCarthy era. ${ }^{11}$ The percentage of respondents asserting that all people feel free was 55.6 in 1954, about the same in 1987, but 13 percentage points lower in 2005. The change from 1954 to 2005 is statistically and substantively significant. The percentage responding that hardly anyone feels free has remained constant over the 50 -year period, indicating that the most important change has been the growth in 2005 in the proportion of the citizenry asserting the quite reasonable view that some do not feel as free to say what they think as they used to. By this accounting, freedom in the United States has clearly declined, even if not necessarily across-the-board, for all citizens.

The respondents were also asked about whether they themselves feel free to speak their mind on political matters. The results are reported in the lower portion of Table 1.

These data also support the conclusion that political freedom has diminished in the United States, although it must be noted that this is within the context of threefourths of the American people claiming to feel free. Moreover, these data are perhaps most interesting for what they reveal about the McCarthy era: At the height of the Red Scare, nearly $85 \%$ of the American people asserted that they enjoyed freedom of speech. Thus, the repression of that era seems to have been sharply focused on (or at least felt by) a relatively small political minority, and perhaps had relatively limited consequences for the larger body politic. ${ }^{12}$ Today, the percentage feeling generally free is about 10 percentage points lower than in 1954.

In some sense, the data in these two tables are entirely consistent. Some people in the United States in fact do not feel free to speak their political minds-indeed, at least one-fourth of the American people are in this category today. So when $45.7 \%$ of the sample reports that they perceive some Americans as not being free, they are accurate in their perceptions. Those who believe that all feel free, or those who believe that hardly anybody feels free, hold, according to these data, inaccurate perceptions.

\footnotetext{
${ }^{11}$ Some might argue that the two time points are incommensurable. Although an interesting argument, there is an important sense in which they are comparable: Both surveys asked questions in an era in which policies had been enacted that limit individual liberty. It therefore makes sense to ask people whether they feel as free to speak their minds now (i.e., at the time of the survey) as compared to the past. The implicit comparison in the question is between the time of emergency and the time before the emergency. Thus, the contexts of the two surveys are in this sense similar and comparable.

${ }^{12}$ Note as well that McCarthyism was quite effective at decimating the Communist movement in the United States (Goldstein 1978). Communists who were in jail, who had gone underground, or who had left the country were obviously unavailable to be interviewed in Stouffer's research.
}

TABLE 2 Perceptions of Available Freedom, Specific Activities, 1987-2005

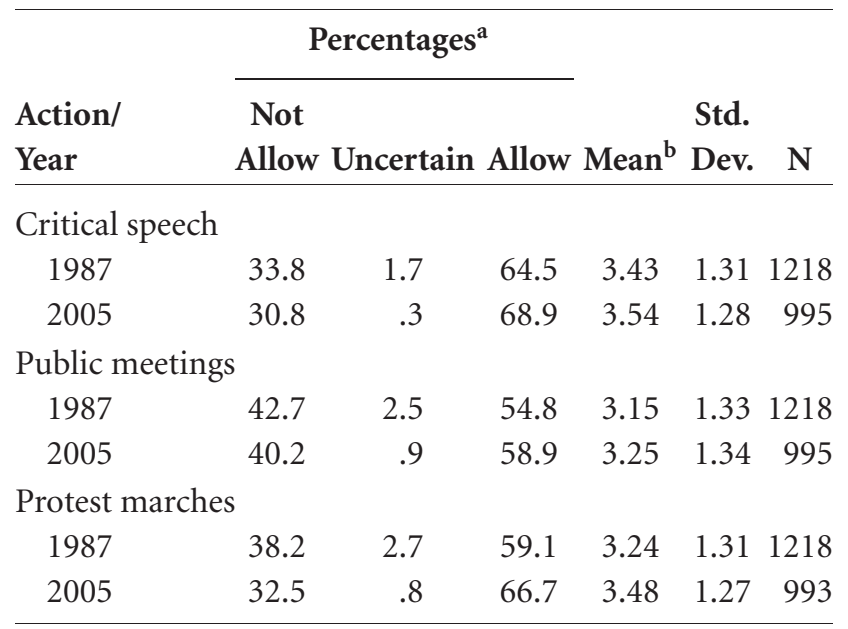

${ }^{\mathrm{a}}$ Item percentages total to $100 \%$ (except for rounding error) across the three columns.

${ }^{\mathrm{b}}$ The responses to these questions were collected on a five-point response set. The means reported here are based on the uncollapsed distributions.

Note: The questions read as follows:

Critical speech: Do you think the government would allow you to make a speech in public criticizing the actions of the government?

Public meetings: Do you think the government would allow you to organize public meetings to oppose the government?

Protest marches: Do you think the government would allow you to organize protest marches and demonstrations to oppose the actions of the government?

Of course, a simple dichotomy responding to a single question constitutes a poor measure of the extent of political freedom in the United States. We therefore asked several additional questions in 2005 about perceived constraints on individual freedom (questions that were also used in the 1987 survey but not in 1954). The replies to these queries are reported in Table 2.

In 2005, substantial majorities of the American people believe that they would be allowed to engage in various types of political protest. Perhaps what is most surprising about these data, however, is the size of the minority believing the government restricts their political expression. Roughly four in 10 Americans, for instance, believe their government would not allow them to organize a public meeting to oppose the government. Only $52.0 \%$ of the respondents judge themselves free to engage in all three of these political activities (data not shown). This strikes me as a remarkably small percentage for an established democracy like the United States, ${ }^{13}$ especially in that the

\footnotetext{
${ }^{13}$ If any evidence of this last assertion is necessary, it is perhaps worth noting that Freedom House scores the United States as "free" (its highest score) on both its political rights and civil liberties subdimensions. See Piano and Puddington (2005).
} 


\section{TABle 3 Perceived Political Freedom, Black and White Mass Publics}

\begin{tabular}{|c|c|c|}
\hline \multirow[b]{2}{*}{ Action } & \multicolumn{2}{|c|}{$\begin{array}{c}\text { Percentage Believing the } \\
\text { Government Would Not } \\
\text { Allow Them to }\end{array}$} \\
\hline & 1987 & 2005 \\
\hline \multicolumn{3}{|c|}{ Organize public meetings } \\
\hline Blacks & 63.7 & 49.5 \\
\hline Whites & 39.5 & 39.0 \\
\hline \multicolumn{3}{|c|}{$\begin{array}{l}\text { Organize protest marches/ } \\
\text { demonstrations }\end{array}$} \\
\hline Blacks & 54.5 & 42.2 \\
\hline Whites & 35.3 & 30.4 \\
\hline \multicolumn{3}{|c|}{$\begin{array}{l}\text { Make speech criticizing } \\
\text { government actions }\end{array}$} \\
\hline Blacks & 55.6 & 47.3 \\
\hline Whites & 29.6 & 27.9 \\
\hline
\end{tabular}

Source: 1987 data: Gibson 1992a, Table 2, p. 342.

activities about which people were questioned are quite innocuous. $^{14}$

Some perspective can be gotten by comparing these data to the comparable survey conducted in 1987 (see also Table 2). The data reveal remarkable similarity across the two periods, with a slight tendency for Americans in 2005 to perceive more freedom available to them than in 1987. For example, in 1987, 38.2\% of the American people felt that they would not be allowed to organize a protest march; by 2005, this figure declined by 5 to 6 percentage points to $32.5 \%$. Perhaps the small amount of change the data reveal is located, however, in a particular subsegment of the overall population.

An analysis of the 1987 survey (Gibson 1992a) revealed enormous racial differences in perceptions of freedom. So as to be able to compare the 2005 and 1987 findings, Table 3 reports the data from the con-

\footnotetext{
${ }^{14}$ It is beyond the scope of this analysis to provide a comprehensive discussion of intolerance, freedom, and democratic theory (see, for example, Gibson 2007 and Gibson and Gouws 2003). The short form of the theory asserts that (a) liberal democracies require unfettered opportunities for political viewpoints to compete in the marketplace of ideas; (b) constraints on competition can arise from governmental actions but also from pressures toward cultural conformity; and (c) mass political intolerance is an important source of both demands for public policy and for conformity. Political tolerance or political freedom should not be equated with democracyand indeed, at the extreme, it is even conceivable that increments in political tolerance actually threaten democracy-but under most circumstances, it is reasonable to hypothesize that greater freedom and tolerance enhance the contestation necessary to democratic governance.
}

temporary period broken down by the race of the respondent. ${ }^{15}$

The first observation to be made on the basis of Table 3 is that substantial racial differences still exist in perceived freedom in 2005. In each instance, African Americans perceive less freedom than whites, and the differences in percentages range roughly from 10 to $20 \%$. The interracial contrasts are not as stark as they were in 1987, but they are still substantial.

On all three activities, black Americans perceive more political freedom today than they did in 1987. For instance, on whether they think they would be allowed to organize public meetings, $63.7 \%$ said they would not in 1987 ; only $49.5 \%$ believe they could not in 2005 . This finding of increasing freedom among blacks stands in contrast to whites, who generally changed remarkably little in perceptions of freedom from 1987 until 2005.

\section{Summary}

Overall, this portion of the analysis supports the following conclusions:

- A substantial proportion of the American people today perceive political freedom to be available to them.

- However, this proportion has declined since the days of McCarthy, and a nontrivial proportion of the population perceives significant constraints on their individual freedom.

- As in earlier findings from the 1980 s, political freedom is strongly related to the race of the individual, with African Americans perceiving considerably less freedom than whites. The gap between blacks and whites has narrowed since 1987, but is still substantial. A remarkable percentage of African Americans does not feel free to express its political views in the contemporary United States.

\section{Political Intolerance: 1954-2005}

As noted in the introduction to this article, Stouffer found that in 1954 virtually all Americans supported depriving admitted Communists of at least some of their political and civil liberties. From this vantage point, intolerance today could not be more widespread than it was in the days of McCarthy. Nonetheless, it is essential to try to measure and assess contemporary levels of intolerance in the United States.

\footnotetext{
${ }^{15}$ Note that the 1987 survey had a bona fide oversample of African Americans and therefore the analysis could give this group much more substantive attention than is possible with the 2005 sample.
} 
TABLE 4 Distribution of Highly Disliked Groups

\begin{tabular}{|c|c|c|c|c|c|c|}
\hline \multirow[b]{2}{*}{ Group } & \multicolumn{2}{|c|}{ Group Affect ${ }^{\mathrm{a}}$} & \multicolumn{4}{|c|}{ Group Rankings } \\
\hline & Mean & $\begin{array}{l}\text { Std. } \\
\text { Dev. }\end{array}$ & $\begin{array}{c}\text { Most } \\
\text { Disliked }\end{array}$ & $\begin{array}{l}2^{\text {nd }} \text { Most } \\
\text { Disliked }\end{array}$ & $\begin{array}{l}3^{\text {rd }} \text { Most } \\
\text { Disliked }\end{array}$ & $\begin{array}{c}\text { Among } 3 \text { Most } \\
\text { Disliked }\end{array}$ \\
\hline Ku Klux Klan & 1.71 & 1.36 & 43.7 & 17.6 & 12.2 & 71.3 \\
\hline Nazis & 1.74 & 1.35 & 12.3 & 35.4 & 18.2 & 63.1 \\
\hline Radical Muslims & 2.94 & 2.12 & 12.9 & 11.4 & 15.7 & 37.4 \\
\hline Atheists & 2.95 & 2.17 & 6.4 & 7.4 & 8.7 & 21.4 \\
\hline Militarists & 2.50 & 2.07 & 6.3 & 5.7 & 10.2 & 20.5 \\
\hline Communists & 3.49 & 2.16 & 4.1 & 6.5 & 10.6 & 19.6 \\
\hline Gay Rights Activists & 4.63 & 2.83 & 3.6 & 5.2 & 8.0 & 15.5 \\
\hline Proponents of Abortion & 4.79 & 2.76 & 2.7 & 3.1 & 4.9 & 9.8 \\
\hline Opponents of Abortion & 4.73 & 2.74 & 1.8 & 2.5 & 2.6 & 6.4 \\
\hline Christian Fundamentalists & 5.46 & 2.36 & 1.4 & 1.9 & 2.0 & 5.0 \\
\hline Total & & & 100.0 & 100.0 & 100.0 & \\
\hline $\mathrm{N}$ & & & 949 & 929 & 809 & \\
\hline
\end{tabular}

${ }^{\text {a }}$ The affect scale varies from 1 to 11 , with high scores indicating greater positive affect. For the group affect ratings, the minimum number of valid respondents is 976 .

How tolerant are the American people today? Unfortunately, answering this question is considerably more difficult in 2005 than it was in 1954. During the McCarthy era, the threat most Americans perceived came from the Left in general and from Communists in particular. The Americans had just concluded a war with the Communists in North Korea; the Cold War with the Soviet Union was heating up (with the very real possibility of nuclear confrontation); and the elites in the United States focused their intolerance on Communists and their "fellow travelers" (e.g., Gibson 1988). To be sure, a wide variety of left-leaning non-Communists were scooped up in the indiscriminate allegations made by McCarthy and his allies (including, of course, Ronald Reagan and the Screen Actor's Guild), but a consensus existed that the dominant threat to the American way of life was from Communists, domestic and international. ${ }^{16}$

Politics is more complicated today, and therefore rather than asking people their views of preselected groups, it is prudent to allow the respondents to tell us which groups and ideas, if any, they find objectionable. The standard technology for accomplishing this is the "least liked" measurement strategy. Developed by Sullivan, Piereson, and Marcus (1982), this approach allows all respondents to identify groups/ideas they dislike.

\footnotetext{
${ }^{16}$ One of the aspects that made Communism so threatening to the Americans was its close association with godlessness. For example, it was during this era that the phrase "under God" was added to the Pledge of Allegiance (e.g., Russo 2004).
}

Tolerance and threat questions are then asked about these groups. Thus, although the nominal group about which the questions are framed varies for each respondent, the questions are "content controlled" in the sense that all individuals are queried about groups they find highly objectionable. The least liked approach to measuring intolerance has been used widely in tolerance research throughout the world (e.g., Gibson and Gouws 2003; Peffley and Rohrschneider 2003).

This approach to measuring intolerance therefore begins by asking the respondents to rate a variety of preselected groups in terms of how much they like or dislike the group. These affect questions were used in part as a means of getting the respondents to think broadly about groups, including those that might be considered by some to be on the fringes of American politics. The respondents were then told they could supplement this list with any other group they disliked a great deal. Next, they were asked to indicate which three groups from the supplemented list they disliked the most. ${ }^{17}$ The selected groups are shown in Table 4 , as are the affect ratings (on a 1 through 11 scale) for each of the groups.

The most commonly disliked group in America today is the Ku Klux Klan, with slightly less than half of the respondents naming the Klan as most disliked, and almost

\footnotetext{
${ }^{17}$ Only $7.2 \%$ of the respondents added a group to the list, and these groups were extremely varied. Only a tiny fraction of those nominating an extra group selected one of these supplemental groups as among their three most disliked groups.
} 
three-fourths putting the KKK on the list of the three most disliked groups. Nazis were also widely named as among the most disliked groups, although they were considerably less likely to be identified as most disliked. Apart from the KKK and Nazis, no other group is targeted by a majority of Americans. Perhaps the single greatest surprise is that atheists (those who are against all religion and churches) would attract the ire of one in five Americans, a figure about equivalent to that for Communists and for those who would do away with elections and let the military run the country.

Is this distribution of groups "pluralistic"? From the frequencies of the most disliked groups alone, one might conclude that it is, since no single group captures the enmity of a majority of the American people. On the other hand, considering groups rated as among the three most disliked groups, a significant majority of Americans rate Klansmen and Nazis as among their three most disliked groups. Beyond these two groups, considerable dissensus emerges: Only slightly more than one-third of the Americans rate Radical Muslims as among their most disliked groups (and Radical Muslims are disliked to the same degree that the Americans dislike atheists). After Muslims, not even one-fourth of the respondents are in agreement about their antipathy toward the groups. Given that the $\mathrm{Ku}$ Klux Klan and Nazi groups are hardly salient in contemporary American politics, one might conclude from these data that the distribution of group antipathy is pluralistic, with little agreement as to who the extremists are, except in the extreme. ${ }^{18}$

The 2005 survey only asked the respondents to name their three most disliked groups. This does not mean, however, that other groups are not equally disliked. To investigate the breadth of groups highly disliked by the American people requires a few additional analytical steps.

1. For each respondent, the maximum positive affect for any group within the three most disliked groups was identified.

2. Affect scores toward the other groups on the list (including any supplementary group nominated by the respondent) were compared to the maximum positive affect found among the three most disliked groups.

3. In counting the number of additional groups with affect scores equal to those of the three most liked disliked group, affect scores indicating neutrality or positive affect (which characterizes only nine respondents)

${ }^{18}$ One can also see support for this assertion in the sizable standard deviations on the group affect continua. Excluding the Klan and Nazis, the standard deviations indicate considerable divergence in the degree to which the various groups are hated. have not been counted. In these instances, the number of tied groups was set equal to zero.

The result of this methodology is an indicator of the number of groups with affect scores as low or lower than the "most liked" group of the three most disliked groups. The distribution of this variable is as follows. Only $15.3 \%$ of the respondents did not rate a group outside the three-most disliked with an equally low level of affect. Thus, in some sense the three most disliked groups are distinctive. A total of $23.1 \%$ named five or more additional groups. The median number of groups named is 3 (with a mean of 2.9). Thus, by any accounting, the three most disliked groups people identify are far from unique. The three most disliked groups are generally highly disliked, but so too are many other groups active in American politics. Group antipathy in the United States is broadly distributed, a consequential finding to which I will return shortly.

Tolerance questions were asked with reference to two groups- the most disliked group and "another highly disliked group." The latter is the third most disliked group if the respondent named one ( $71.2 \%$ of the respondents). If no third group was named, then the second most disliked group was used in the questions $(23.1 \%) .{ }^{19}$ As will be demonstrated in the analysis below, not much difference exists for most respondents between their perceptions and judgments of the two groups about which we asked.

The respondents were asked three tolerance questions about the most disliked group and what I refer to as another highly disliked group. Following theories of liberal democracy (e.g., Dahl 1971), and extant research on political intolerance (e.g., Gibson and Gouws 2003), the queries concerned whether these groups should be allowed to speak, demonstrate, and run as candidates for office. The results are reported in Table 5.

The data in this table document widespread political intolerance in the United States today. For each of the six questions, more than one-half of the respondents gave an intolerant reply to our query. Only something on the order of one-third of the respondents expressed a tolerant viewpoint. Little variation exists across the various activities, and surprisingly small differences can be found between the judgments of the most disliked group and another highly disliked group. Indeed, more than one-half of the sample $(54.1 \%)$ gave no tolerant replies to the questions about the most disliked group; only a somewhat smaller

\footnotetext{
${ }^{19}$ For the minuscule proportion of respondents naming no second or third group, the questions asked about either "those who advocate creating a new, separate nation for only white people in America" or "those who advocate creating a new, separate nation for only black people in America," depending upon the respondent's race.
} 
TABLE 5 Political Intolerance, 2005

\begin{tabular}{|c|c|c|c|c|c|c|}
\hline \multirow[b]{2}{*}{ Group/Activity } & \multicolumn{3}{|c|}{ Percentages $^{\mathrm{a}}$} & \multirow[b]{2}{*}{ Mean $^{b}$} & \multirow[b]{2}{*}{ Std. Dev. } & \multirow[b]{2}{*}{$\mathbf{N}$} \\
\hline & Tolerant & Uncertain & Intolerant & & & \\
\hline \multicolumn{7}{|l|}{ Most Disliked Group } \\
\hline Speak & 35.8 & 6.6 & 57.5 & 3.45 & 1.28 & 971 \\
\hline Run for office & 29.5 & 8.9 & 61.6 & 3.56 & 1.29 & 972 \\
\hline Demonstrate & 29.2 & 11.1 & 59.7 & 3.56 & 1.20 & 972 \\
\hline Tolerance Index ${ }^{c}$ & - & - & - & 3.52 & 1.08 & 972 \\
\hline \multicolumn{7}{|l|}{ Another Highly } \\
\hline \multicolumn{7}{|l|}{ Disliked Group } \\
\hline Speak & 41.3 & 7.3 & 51.4 & 3.26 & 1.23 & 960 \\
\hline Run for office & 37.2 & 8.4 & 54.4 & 3.32 & 1.26 & 960 \\
\hline Demonstrate & 33.2 & 9.3 & 57.4 & 1.18 & 3.42 & 962 \\
\hline Tolerance Index ${ }^{c}$ & - & - & - & 3.33 & 1.03 & 972 \\
\hline
\end{tabular}

${ }^{a}$ Item percentages total to $100 \%$ (except for rounding error) across the three columns.

${ }^{b}$ The responses to these questions were collected on a five-point response set. The means reported here are based on the uncollapsed distributions.

${ }^{\mathrm{c}}$ This index is the mean of the responses to the three tolerance items for each of the two groups.

\section{TABLE 6 Political Tolerance, Fixed Groups, 2005}

\begin{tabular}{|c|c|c|c|c|c|c|}
\hline \multirow[b]{2}{*}{ Group } & \multicolumn{3}{|c|}{ Percentages $^{\mathrm{a}}$} & \multirow[b]{2}{*}{ Mean $^{b}$} & \multirow[b]{2}{*}{ Std. Dev. } & \multirow[b]{2}{*}{$\mathrm{N}$} \\
\hline & Support Ban & Uncertain & Oppose Ban & & & \\
\hline Radical Muslims & 56.8 & 4.3 & 38.9 & 2.64 & 1.33 & 984 \\
\hline Atheists ${ }^{c}$ & 46.9 & 4.0 & 49.1 & 2.93 & 1.36 & 983 \\
\hline U.S. Communists & 53.6 & 5.4 & 41.0 & 2.72 & 1.32 & 990 \\
\hline Religious Fundamentalists & 39.1 & 8.3 & 52.6 & 3.11 & 1.22 & 984 \\
\hline
\end{tabular}

Note: The question referred to a group that "wanted to hold public rallies and demonstrations in your community to advance their cause, but that the authorities decided to prohibit it," and asked how the respondent would "react to such a ban by the authorities of a public demonstration" by the group.

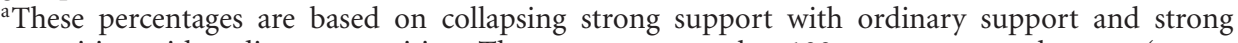
opposition with ordinary opposition. The percentages total to 100 percent across the rows (except for rounding errors).

${ }^{\mathrm{b}}$ High scores indicate greater degrees of tolerance. The means reported here are based on the uncollapsed distributions.

"Atheists" is the commonly used shorthand for the actual stimulus, which was "someone who is against all religion and churches.”

percentage (44.5\%) would tolerate none of these activities by the other highly disliked group (data not shown). By any accounting, intolerance appears to be fairly common in the United States.

As Table 4 revealed, Communists are not widely liked in the United States; only $5.2 \%$ of the respondents expressed any degree of positive affect toward Communists, although $21.5 \%$ held neutral views (data not shown). For $73.4 \%$ of the American people, Communists are disliked. As Table 4 also shows, however, only $19.6 \%$ of the Americans named Communists as among their three most dis- liked groups. From these data, direct comparison to the McCarthy era therefore does not seem feasible.

However, the 2005 survey also asked all respondents tolerance questions referring to four preselected groups. ${ }^{20}$ Table 6 reports the degree to which the American people are willing to tolerate demonstrations by these four groups. The question specifically asked about how the respondent would react to a decision by local authorities

${ }^{20}$ For a comparison of the two approaches to measuring political tolerance see Gibson (1992b). 
to ban a public demonstration by these various groups. The groups were selected to represent a variety of ideological points of view, with two groups (Communists and atheists) drawn from the leftward portion of the ideological continuum, and two groups (Radical Muslims and religious fundamentalists) representing the right. These groups vary in the degree to which the American people dislike them, with $79.6 \%$ expressing some antipathy toward atheists, 78.5\% toward Radical Muslims, and 73.4\% toward Communists, but only $39.1 \%$ disliking fundamentalists. These questions represent difficult tests of tolerance, since they explicitly posit that the authorities had decided not to allow the demonstration (although the questions do not indicate why). Therefore, a tolerant reply requires that the respondent go against that decision.

Table 6 reveals that about one-half of the American people would today support banning a demonstration by Communists. Their views toward Communists seem not to be unique, inasmuch as a roughly similar percentage would approve of a ban on demonstrations by Radical Muslims and even atheists (those who are against all religion and churches). ${ }^{21}$ Of the groups about which we asked, only religious fundamentalists are tolerated by a majority of the American people, although it should be strongly reiterated that these figures for each group include respondents who are actually sympathetic toward the group/idea (and therefore these questions are not a fair test of political tolerance). Only $28.9 \%$ of the American people would tolerate a demonstration by each of these four groups; $33.9 \%$ would tolerate none of the groups (data not shown). ${ }^{22}$

\section{Summary}

How common is intolerance in the United States today compared to the McCarthy era? In response to a question in 1954 about whether a Communist should be allowed to give a speech, $68 \%$ of the American people replied "no." In 2005, 54\% would ban a Communist demonstration, and a roughly similar proportion would not allow a speech by their most disliked group or by another highly disliked group. Thus, the most appropriate conclusion is that intolerance is less widespread in 2005 than it was in 1954 ,

\footnotetext{
${ }^{21}$ The average intercorrelation among these items is .64. When factor analyzed, this set of items exhibits a strongly unidimensional structure, which indicates that a general propensity toward intolerance dominates the responses to the group-specific statements.

${ }^{22}$ Just as with perceptions of freedom, racial differences in political intolerance are statistically significant. Compared to whites, blacks are more intolerant, but only slightly so.
}

although the level of intolerance of the American people today is still remarkably high.

\section{The Connections Between Freedom and Intolerance in the United States Today}

Although a full analysis of the causes and consequences of these attitudes is beyond the scope of this article, it is worthwhile to consider the types of Americans who perceive freedom and who are intolerant. Such an inquiry provides valuable evidence on whether "pluralistic intolerance" has any political consequences. This analysis focuses on the group sympathies of individuals and the degree to which they are associated with perceived freedom and political tolerance. For instance, one might hypothesize that those who express favorable views toward Radical Muslims perceive less freedom as being available to them, given the high level of antipathy toward Muslims in the United States.

Based on the various groups about which we queried the respondents as a prelude to the tolerance questions, Table 7 reports data on who feels free to express themselves and who does not. The number of respondents analyzed varies greatly across groups (see the table), since few Americans are positively oriented toward Radical Muslims, while many think favorably of Conservatives. ${ }^{23}$ The second data column in the table reports the percentage of respondents asserting that the government would not allow them all three political activities (as reported in Table 2).

The group most unfree in the United States today is those holding sympathetic views toward Radical Muslims. ${ }^{24}$ Sympathizers with militarists and Communists are not far behind in perceiving constraints on their freedom. What is perhaps more interesting, however, is the relatively common constraints on freedom perceived by Christian Fundamentalists and by those who oppose abortion rights. More than one-half of these mainstream groups believe they cannot exercise full political freedom in the United States today. It is also noteworthy that the respondents least likely to perceive repression are those sympathetic toward Gay Rights Activists and atheists, groups that

\footnotetext{
${ }^{23}$ Groups with whom fewer than 30 respondents sympathized were excluded from this analysis.

${ }^{24}$ Anecdotal reports are often found in the media about the constraints Muslims in the United States feel on their freedom. See for example MacFarquhar (2006). For a more systematic but still limited analysis see Henderson et al. (2006).
} 


\section{TABle 7 Perceived Constraints on Political Freedom According to Group Sympathies}

\begin{tabular}{|c|c|c|c|c|}
\hline \multirow[b]{2}{*}{$\begin{array}{l}\text { Sympathizers } \\
\text { with ... }\end{array}$} & \multirow[b]{2}{*}{$\mathbf{N}$} & \multirow[b]{2}{*}{$\begin{array}{c}\text { \% Perceiving } \\
\text { Some } \\
\text { Freedom } \\
\text { Constraints }\end{array}$} & \multicolumn{2}{|c|}{$\%$ Intolerant } \\
\hline & & & $\begin{array}{c}\text { Most } \\
\text { Disliked } \\
\text { Group }\end{array}$ & $\begin{array}{c}\text { Other } \\
\text { Disliked } \\
\text { Group }\end{array}$ \\
\hline $\begin{array}{l}\text { Gay Rights } \\
\text { Activists }\end{array}$ & 246 & 39.0 & 64.2 & 59.3 \\
\hline Atheists & 34 & 41.2 & 58.8 & 38.2 \\
\hline $\begin{array}{l}\text { Pro-Abortion } \\
\text { Rights }\end{array}$ & 251 & 41.8 & 67.9 & 63.3 \\
\hline Liberals & 371 & 43.4 & 71.2 & 69.8 \\
\hline Conservatives & 452 & 43.4 & 74.1 & 71.4 \\
\hline All Americans & 995 & 48.0 & 73.2 & 71.5 \\
\hline $\begin{array}{l}\text { Anti-Abortion } \\
\text { Rights }\end{array}$ & 216 & 51.9 & 78.6 & 75.5 \\
\hline $\begin{array}{l}\text { Christian } \\
\text { Fundamentalists }\end{array}$ & 280 & 55.7 & 80.1 & 77.2 \\
\hline U.S. Communists & 50 & 60.0 & 79.6 & 81.6 \\
\hline Militarists & 46 & 60.9 & 86.9 & 81.8 \\
\hline Radical Muslims & 34 & 67.6 & 70.6 & 55.9 \\
\hline
\end{tabular}

are fairly widely disliked in American politics. ${ }^{25}$ Certainly there is nothing in these data that suggests a dominant relationship between the degree to which radical views are espoused and perceptions of constraints on political freedom.

Perhaps the most unexpected of these findings is that so many Christian Fundamentalists perceive limits to their political freedom. Explaining why requires some speculation. As Christian Fundamentalists have flexed their political muscles in recent times, they may have become disappointed at the degree to which government stands as an impediment to achieving their goals. From prayers in schools and at football games to the display of religious symbols on state-owned property, fundamentalists are often thwarted today by the government. Perhaps the relationship reported here can be understood as a function of the degree of demand made on the public space. As groups demand more-as expectations rise-they are more likely to see government as unresponsive. Some are willing to make the inferential leap from lack of respon-

\footnotetext{
${ }^{25}$ Although based on only 10 observations (groups), a strong relationship exists between antipathy toward the group and the degree to which its sympathizers feel unfree $(r=-.53)$ : Groups that are disliked more by the American people perceive less political freedom.
}

siveness to affirmative restrictions on political freedom. Perhaps those who want least from the public domain believe they have the most freedom available for their use. ${ }^{26}$

From a more theoretical vantage point, only a minority of the American people would support banning a demonstration by Christian Fundamentalists (as is documented in Table 6), yet supporters of Christian Fundamentalists perceive substantial constraints on their freedom. I take this as evidence that for the pernicious consequences of intolerance to materialize it is not necessary that a majority of the people be intolerant (as is implicitly assumed by the subtheory of pluralistic intolerance). Where significant pockets of intolerance exist, many citizens become fearful that even minority intolerance can be consequential, and they fear for their political freedom.

Table 7 also reports the levels of intolerance of those who sympathize with these groups. The first thing to note about the figures in this table is that intolerance is widespread, and, for most, it matters little whether the intolerance concerns the most disliked or another highly disliked group. ${ }^{27}$ In the tolerance columns, there is only a single instance in which intolerance does not predominate: Among those sympathetic to atheists, only $38.2 \%$ would not tolerate political activity by the other highly disliked group. In all other instances, the majority is intolerant. Some variability exists in intolerance: For instance, the range of intolerance directed at the most disliked group is from $58.8 \%$ to $86.9 \%$ : Intolerance predominates, to say the least.

It is noteworthy that at both the micro- and macrolevels, a strong relationship exists between the perception that one's liberty is restricted and political intolerance. Although based on only 10 groups (but confirmed as well at the microlevel), the correlation between group sympathizers' intolerance and perceptions of restraints on their freedom is .65: Those who feel more unfree are likely to be more intolerant. The nature of the causal relationship between these two attitudes cannot be dissected-perhaps because they perceive themselves as

\footnotetext{
${ }^{26}$ This may be one explanation of the high level of political freedom asserted by the American people during the days of McCarthyism. And indeed, perhaps the most pernicious form of political repression is that which inculcates low expectations. Understanding false consciousness is a task for which survey research is not well suited, however.

${ }^{27}$ For each of the groups listed in Table 7, the modal most disliked group is the Ku Klux Klan, and the modes range from $36.7 \%$ (those sympathetic to anti-abortion rights groups) to $73.5 \%$ (Radical Muslims). In most instances, the mode exceeds 50\%. In terms of the other highly disliked group, the modal group is the same for all: Nazis. However, the modes range narrowly from $15.4 \%$ (those who sympathize with U.S. Communists) to $25.9 \%$ (atheist sympathizers), indicating a great deal of dispersion in the groups named as the other highly disliked group.
} 
not having freedom, it is easier to justify denying freedom to others-but a close connection exists between perceptions that the government should deny civil liberties to disliked groups and that it does deny civil liberties to groups to which one is favorably predisposed.

\section{Theoretical Implications}

This comparison between freedom and tolerance during the McCarthy era and today in the United States supports several important conclusions. Most interesting, even though intolerance is perhaps less widespread today (although not greatly so), the political freedom perceived by citizens is less than in the days of the Red Scare. This is an important puzzle that requires some additional thought and consideration.

Perhaps the reduced level of political freedom today flows from the diffuse nature of intolerance in the contemporary United States. Rather than being focused only on a single political ideology (Communists), intolerance is reasonably dispersed across the ideological continuum, with some Americans preferring not to tolerate groups on the left, but others focusing their intolerance on groups on the right. Not all members of these disliked groups, of course, perceive the intolerance and the associated limits on their individual freedom. But because some Communists are not tolerated and do not feel free, and because some Religious Fundamentalists are not tolerated and do not feel free, and because some of those sympathetic to other groups are not tolerated and do not feel free, the cumulative effect is more widespread feelings of lack of freedom today than in the McCarthy era.

Much has been written in the tolerance literature about the effect of pluralistic versus focused intolerance. The latter describes the McCarthy era, when nearly all citizens recognized the nature of the threat to the political system, whereas the former refers to disagreement among citizens as to where the primary threats lie. Conventional wisdom is that pluralistic intolerance tends to be benign, since disagreement on the targets of intolerance prevents a "critical mass" from forming and being effective at demanding repressive action from the government. But the evidence of this analysis is that pluralistic intolerance may in fact be malevolent in the sense that many segments of the population are subject to perceptions of restrained freedom. If pluralistic intolerance is actually multidimensional intolerance-as it seems to be in the contemporary United States-then its consequences may be quite different than ordinarily presumed.
This last conjecture also points to the possibility that restraints on freedom are not exclusively or perhaps even primarily from the government. Expectations and norms widespread in the culture can inhibit free expression. Indeed, perhaps the most serious constraint of the McCarthy era was in the way in which ordinary citizens repressed each other, by which I mean they provided strong disincentives for the expression of anything remotely resembling a "radical" viewpoint. Within such a political climate, citizens often learn to "keep their mouths shut," which, as Noelle-Neumann (1984) has argued, can create a "spiral of silence" in which those holding minority viewpoints are fearful of expression since they perceive their own views as unusual, which in turns leads to silence, which makes minority viewpoints even less commonly voiced, which in turns leads to silence, and so on (but see Huckfeldt, Johnson, and Sprague 2005). To the extent that a country's political culture does not encourage and reward expressions of a variety of points of view, political freedom is unlikely to be widespread.

Finally, more attention ought to be paid to the ways in which social networks enhance or limit individual freedom. Gibson (1992a) has shown that network homogeneity constrains speech, a finding reinforced by Mutz (2002). Perhaps disincentives to the free expression of opinions are more a function of interpersonal interactions than the nefarious schemes of government. Since we actually know little about the internal dynamics of these processes, understanding the social processes contributing to intolerance, conformity, and the loss of freedom is a matter of considerable importance for students of American politics.

Perhaps the most urgent task of future research is to investigate more comprehensively the interconnections among intolerance, freedom, and repression. The subtheory of pluralistic intolerance is undoubtedly too simplistic to be able to account for the mobilization of intolerance into repression; many other factors are surely involved. Majority opposition to an idea or a group seems not to be necessary for dissidents to fear for their individual freedom. Perhaps from a policy-making viewpoint, whether the majority supports repression is important. But from the perspective of cultural constraints on freedom, it seems to matter much less whether a majority, or just a significant number of people, would not tolerate political activity by a group. Is the United States embarking on a new era of rampant intolerance and political repression, mimicking McCarthyism? Perhaps not. But even in the absence of widespread, focused intolerance, the unwillingness to allow minority viewpoints to be expressed and advocated appears to be pernicious. 


\section{References}

Bachrach, Peter. 1967. The Theory of Democratic Elitism: A Critique. Boston: Little, Brown.

Baker, Steward A., and John Kavanagh, eds. 2005. Patriot Debates: Experts Debate the USA Patriot Act. Chicago: American Bar Association.

Brown, Ralph S. 1958. Loyalty and Security. New Haven, CT: Yale University Press.

Dahl, Robert A. 1971. Polyarchy. New Haven, CT: Yale University Press.

Davis, Darren W. 2007. Negative Liberty: Public Opinion and the Terrorist Attacks on America. New York: Russell Sage Foundation.

Davis, Darren W., and Brian D. Silver. 2004. "Civil Liberties vs. Security: Public Opinion in the Context of the Terrorist Attacks on America." American Journal of Political Science 48 (1): 28-46.

Gibson, James L. 1986. "Pluralistic Intolerance in America: A Reconsideration.” American Politics Research 14 (4): 267-93.

Gibson, James L. 1988. "Political Intolerance and Political Repression during the McCarthy Red Scare." American Political Science Review 82 (2): 511-29.

Gibson, James L. 1992a. “The Political Consequences of Intolerance: Cultural Conformity and Political Freedom." American Political Science Review 86 (2): 338-56.

Gibson, James L. 1992b. "Alternative Measures of Political Tolerance: Must Tolerance Be 'Least-Liked'?" American Journal of Political Science 36(2): 560-77.

Gibson, James L. 1993. "Political Freedom: A Sociopsychological Analysis." In Reconsidering the Democratic Public, ed. George E. Marcus and Russell L. Hanson. University Park: The Pennsylvania State University Press, 113-37.

Gibson, James L. 1998. "Putting Up with Fellow Russians: An Analysis of Political Tolerance in the Fledgling Russian Democracy." Political Research Quarterly 51(1): 37-68.

Gibson, James L. 2007. "Political Intolerance.” In Oxford Handbook of Political Behavior, ed. Russell J. Dalton and HansDieter Klingemann. New York: Oxford University Press, 32341.

Gibson, James L, and Amanda Gouws. 2003. Overcoming Intolerance in South Africa: Experiments in Democratic Persuasion. New York: Cambridge University Press.

Goldstein, Robert Justin. 1978. Political Repression in Modern America. Cambridge: Schenkman.

Henderson, Nicole, Christopher W. Ortiz, Naomi F. Sugie, and Joel Miller. 2006. Law Enforcement \& Arab American Community Relations after September 11, 2001: Engagement in a Time of Uncertainty. Vera Institute of Justice, June 2006. http:// www.vera.org/publications/publications_5.asp?publication id $=353$ [accessed 6/15/2006].

Huckfeldt, Robert, Ken'ichi Ikeda, and Franz Urban Pappi. 2005. "Patterns of Disagreement in Democratic Politics: Comparing Germany, Japan, and the United States." American Journal of Political Science 49(3): 497-514.
Huckfeldt, Robert, Paul E. Johnson, and John Sprague. 2005. Political Disagreement: The Survival of Diverse Opinions within Communications Networks. New York: Cambridge University Press.

Lazarsfeld, Paul, and Wagner Thielens, Jr. 1958. The Academic Mind. Glencoe, IL: Free Press.

MacFarquhar, Neil. 2006. "U.S. Muslims Say Terror Fears Hamper Their Right to Travel." New York Times Vol. CLV, No. 53,597, Thursday, June 1, 2006, National Edition. pp. A1, A20.

McCann, Stewart J. H. 1998. “The Extended American Social, Economic, and Political Threat Index (1788-1992).” The Journal of Psychology 132(4): 435-49.

Mutz, Diana. 2002. "Cross-cutting Social Networks: Testing Democratic Theory in Practice." American Political Science Review 96(1): 111-26.

Noelle-Neumann, Elisabeth. 1984. The Spiral of Silence: Public Opinion, Our Social Skin. Chicago: University of Chicago Press.

Peffley, Mark, and Robert Rohrschneider. 2003. "Democratization and Political Tolerance in Seventeen Countries: A Multi-level Model of Democratic Learning." Political Research Quarterly 56(3): 243-57.

Peffley, Mark, and Lee Sigelman. 1990. "Intolerance of Communists during the McCarthy Era: A General Model." Western Political Quarterly 43(1): 93-111.

Piano, Aili, and Arch Puddington, eds. 2005. Freedom in the World 2005: The Annual Survey of Political Rights and Civil Liberties. New York: Freedom House.

Rasinski, Kenneth A., Jennifer Berktold, Tom W. Smith, and Bethany L. Albertson. 2002. America Recovers: A Follow-Up to a National Study of Public Responses to the September $11^{\text {th }}$ Terrorist Attacks. Chicago: NORC, University of Chicago.

Russo, Charles J. 2004. "The Supreme Court and the Pledge of Allegiance: Does God Still Have a Place in American Schools?" Brigham Young University Education and Law Journal 2004(1): 301-30.

Stone, Geoffrey R. 2004. Perilous Times: Free Speech in Wartime from the Sedition Act of 1798 to the War on Terrorism. New York: W. W. Norton \& Company.

Stouffer, Samuel C. 1955. Communism, Conformity and Civil Liberties. New York: Doubleday.

Sullivan, John L., James E. Piereson, and George E. Marcus. 1982. Political Tolerance and American Democracy. Chicago: The University of Chicago Press.

Sullivan, John L., Michal Shamir, Patrick Walsh, and Nigel S. Roberts. 1985. Political Tolerance in Context: Support for Unpopular Minorities in Israel, New Zealand, and the United States. Boulder, CO: Westview Press.

Sullivan, John L., and John E. Transue. 1999. "The Psychological Underpinnings of Democracy: A Selective Review of Research on Political Tolerance, Interpersonal Trust, and Social Capital." Annual Review of Psychology 50: 625-50.

Tocqueville, Alexis de. 1948. Democracy in America. Trans. Henry Reeve. 2 vols. New York: Knopf. 